Group Theory 
This page intentionally left blank 


\section{Group Theory}

Birdtracks, Lie's, and Exceptional Groups

\section{Predrag Cvitanović}


Copyright (C) 2008 by Princeton University Press

Published by Princeton University Press

41 William Street, Princeton, New Jersey 08540

In the United Kingdom: Princeton University Press

6 Oxford Street, Woodstock, Oxfordshire 0X20 1TW

All Rights Reserved

Library of Congress Cataloging-in-Publication Data

Cvitanović, Predrag.

Group theory: Birdtracks, Lie's, and exceptional groups / Predrag Cvitanović.

$$
\text { p. cm. }
$$

Includes bibliographical references and index.

ISBN: 9780691118369 (alk. paper) 0691118361 (alk. paper) 1. Group theory. I. Title. QA174.2.C85 2008

$512^{\prime} \cdot 2-\mathrm{dc} 22$

British Library Cataloging-in-Publication Data is available

This book has been composed in $\mathrm{LAT}_{\mathrm{E}} \mathrm{X}$

The publisher would like to acknowledge the author of this volume for providing the camera-ready copy from which this book was printed.

Printed on acid-free paper. $\infty$

press.princeton.edu

Printed in the United States of America

10987654321 
dedicated to the memory of

Boris Weisfeiler and William E. Caswell 
This page intentionally left blank 